\title{
Indonesian Readiness for Digital Economy: Case on Trade Flows in ASEAN Region
}

\author{
Iwan Hermawan \\ Expertise Agency and Secretary-General \\ Indonesian House of Representative \\ Jakarta, Indonesia \\ iwan.hermawan@dpr.go.id
}

\begin{abstract}
The purpose of this study was to analyze Indonesian readiness for digital economy, case on trade flow in the ASEAN region. This study employed a quantitative approach with Gravity Model. The secondary data in the form of panel data period year 2004-2016 (annual) and includes ASEAN-10 countries. The variable digital economy readiness was a main explanatory variable interest and represented by readiness index. The all data sourced come from Comtrade, IMF, World Bank, World Economic Forum, and Indonesian Ministry of Trade. The analytical method used Poisson Pseudo Maximum Likelihood (PPML) and it was resolved with software of Stata 13. The results confirmed that Indonesian readiness for digital economy would affect positively trade flow of tangible and intangible product in the ASEAN market. In detail, fixed broadband internet tariffs and quality of educational system significantly influenced ICT trade flow in ASEAN market. While individual readiness became crucial factor effect trade in service in ASEAN market. Therefore, in order to prepare Indonesian for digital ecosystem, issue of accessibility and digital literacy by individual must be considered by the government. There are prerequisites that must be prepared when grabbing benefits of the momentum of the digitalization era.
\end{abstract} Model

Keywords - Trade, digital, ASEAN, readiness, Gravity

\section{INTRODUCTION}

Indonesia is predicted to enjoy the benefits of digital era momentum. Unfortunately, it would be disrupted if the technological commodities needs are hampered, particularly through trade flow, in the short and medium term. ASEAN Economic Community (AEC) corridor open up great opportunity, making technology commodities available to support pace of national digitalization. When the ASEAN decided to pursue economic integration as inscribed in the AEC blueprint, then free flow trade of commodities and also services product were main element of a single market and production base. Both of them reflect how far and how deep of "digitalization vibe" happen in a country or ASEAN region.

We can see deep down from the potential of domestic digital market. Indonesia is an attractive market because of large population, increasing personal consumption average by 5,4 percent annually period 2018-2022 (half of it flows to e-commerce sector), and the middle class group are upgraded by 300 percent period 2017-2030 as the biggest number in ASEAN-6 [1]. Based on Ernst \& Young's analysis, the value of online business sales in Indonesia increases by 40 percent annually. There are around 93.4 million internet users and 71 million smartphone users in Indonesia [2]. Moreover, the results of the Polling Indonesia feat Asosiasi Penyelenggara Jasa Internet Indonesia (APJII), the number of internet users in Indonesia grew 10.12 percent, there were 171.17 million people or 64.8 percent who were connected to the internet in 2019 or this amount increased than 2017 [3]. These conditions for sure encourage the use of digital stuff.

To reach out and make it truly benefit or achieve success in doing business in the digital era, we need to build a good ecosystems and innovation, especially in ASEAN region. Diversity of readiness of each country show the differences in resources allocation and government policies. Trade flows must be considered so that the digital era remains in its place. Many factors will influence it, including readiness of infrastructure, affordability, skills, business, government, and so on.

Indonesian people are actually already accustomed to using digital technology. Indonesia will be the fourth largest active smartphone user in the world after China, India, and America [4]. But many parties doubt the benefit because of many challenges and obstacles, including geographical issue, lack of human resource skills because of low education so that hinder service sector development, and prejudiced policy maker toward trade. By taking the trade flow in ASEAN region, we aim to analyze Indonesian readiness for digital economy through ICT and service trade flow in the ASEAN market.

So many studies related with this theme was numerous. But unfortunately there was not yet scrutinize Indonesia's ICT case study and in ASEAN region. Some of them, i.e. Suominen [5], Manyika et al. [6], Vogiatzoglou [7], and Zhongwei [8].

\section{METHOD}

\section{A. Data and Source}

We used panel data with time series year 2013-2016 and cross section 10 ASEAN countries, namely Indonesia, Malaysia, Thailand, Brunei Darussalam, Singapore, Philippines, Vietnam, Cambodia, Myanmar, and Laos. The data was sourced from World Bank, Comtrade, World Integrated Trade Solution (WITS), Centre d'Études Prospectives et d'Informations Internationales (CEPII), International Monetary Fund (IMF), Indonesian Statistic, World Economic Forum (WEF), and so on. Stata 13 software was employed to process the data

The commodities were divided into 2, namely (1) Information Communication Technology (ICT) HS 2012-6 digits as classified by UNCTAD (in value). ICT01 includes computers and peripheral equipment, ICT02 includes communication equipment, ICT03 include consumer 
electronic equipment, ICT04 includes electronic components, and ICT05 includes miscellaneous, and (2) service includes auxiliary activities but not insurance and pension funding (in value). This data sourced by Global Trade Analysis Project (GTAP) with base data year 2004, 2007, and 2011. Both of them would become very important product related to the digital era. ICT as a tool or stuff that supports digitization activities. Whereas service becomes popular product that predicted grow rapidly, those are like key and lock. Data limitations, became a huge challenge in this research.

\section{B. The Approach Method}

The Gravity Model was used in this research. This model has been applied by other researchers and with various publications. According Anderson [9] and Feenstra et al. [10], the simple gravity equation explains a great deal about the data on bilateral trade flows and was consistent with several theoretical models of trade.

Generally, the final form of gravity specification was presented in equation (1), where the sub-index $i$ and $j$ refer to the origin and partner country, respectively, whilst $t$ refers to the year:

$$
\begin{aligned}
\mathrm{M}_{\mathrm{ijt}}=\alpha+ & \beta_{1} \operatorname{lngdpo}_{\mathrm{it}}+\beta_{2} \text { lngdpp }_{\mathrm{it}}+\beta_{3} \text { ddist }_{\mathrm{it}}+ \\
& \beta_{4} \text { linder }_{\mathrm{it}}+\beta_{5} \text { lris }_{\text {it }}+\beta_{6} \mathrm{cpio}_{\mathrm{it}}+ \\
& \beta_{7} \text { Lang }_{\mathrm{it}}+\varepsilon
\end{aligned}
$$

Where:

$\mathrm{M}_{\mathrm{ijt}} \quad$ : import of country $j$ from country $i$ (mio USD), the data came from WITS and GTAP.

$\operatorname{lgdpo}_{\text {it }}: \log$ GDP of origin country (mio USD), the data came from IMF.

$\operatorname{lgdpp}_{\text {it }} \quad: \log$ GDP of destination country (mio USD), the data came from IMF.

cpio $_{\text {it }}$ : Consumer price index of origin country (percentage), the data came from IMF.

ddist $_{\text {it }} \quad$ : economic distance between the capital cities of the importing and exporting country $(\mathrm{km})$, the data were obtained from CEPII.

linder $_{\text {it }} \quad$ : log gap between GDP per capita origin and destination (USD).

lris $_{\text {it }} \quad: \log$ readiness index and another readiness indicators, including (a) infrastructure (represented by int'l internet bandwidth, kb/s per user), (b) affordability (represented by fixed broadband internet tariffs, PPP USD/month), and (c) skill (represented by quality of educational system). The data came WEF.

Lang $_{\text {it }} \quad$ : dummy language, the data came from CEPII

$\alpha \quad$ : intercept

$\beta_{1}-\beta_{7} \quad:$ parameter estimation

$\varepsilon \quad$ : error term

Along with zero-observations and the heteroscedasticity problem often occurs in trade data, the Pseudo Poisson Maximum Likelihood (PPML) was a robust approach [11]. This approach has been used in a number of estimations of Gravity equations, such as Westerlund \& Wilhelmsson [12], and Akhvlediani \& Śledziewska [13]. PPML employed here was PPML fixed effect and to ensure PPML was robust, this research conducted the Ramsey Regression Equation Specification Error Tests (RESET).

\section{RESULT AND ANALYSIS}

The results of data processing were presented in Table I, 2, 3, and 4. Those all equations that have been repeated through re-specification process to get the fit model. The sign of parameters estimation was in accordance with the theory. Table I showed briefly that GDP, Linder effect, Indonesian readiness index, and dummy language effected Indonesian ICT's import. Among those variables, surprisingly when there was similar language, it would increase ICT import USD25.23 million, ceteris paribus. Exactly as told by Lohmann [14] where "my language is language barriers" may be more important to international trade than previously thought.

We would focus on Indonesian readiness only and it didn't mean remain variables was not important. Indonesian readiness in welcoming of digital era would affect positively of ICT import in ASEAN market. However, Indonesia needs various commodities that are used to support the operation of business entities or activities that are digitalized. If Indonesian readiness rises by one unit (score) then it will increase ICT imports from ASEAN market by USD1 million, assumed ceteris paribus.

TABLE I. PARAMETER ESTIMATION RESUlT OF TRADE IN ITC COMMODITIES (MODEL 1A)

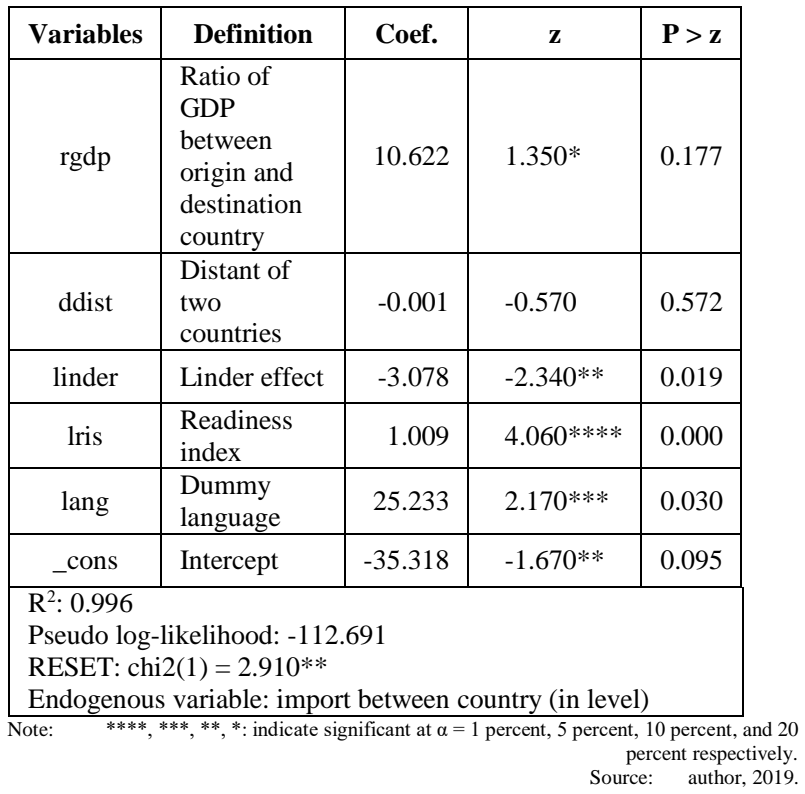

Readiness index referred from WEF. It contained so many indicators, et least 10 pillars, from political until social impact. As a general-purpose technology, the impact of ICTs extends well beyond productivity gains. ICTs act as a vector of social development and transformation by improving access to basic services, improving connectivity, and creating employment opportunities [15].

If we look it deep down, what indicators of readiness play an important role, it presents in Table II. There were two factors of readiness that influenced ICT trade flow in ASEAN market, namely (1) fixed broadband internet tariffs and (2) quality of educational system.

Readiness index in WEF was calculated by some indicators, namely (a) infrastructure, (b) affordability, and (c) skills. The fixed broadband internet tariffs were one of affordability scope and quality of educational system was 
included in skills corridor. So, if fixed broadband internet tariffs increased 1 percent, then ICT import would decrease by USD0.15 million, ceteris paribus. Indonesian government has a huge homework related with fixed broadband internet tariffs because it is relatively more expensive than other ASEAN countries. Based on CupoNation study found Indonesia was runner up of six countries in ASEAN countries, with expensive fixed broadband internet tariffs by Rp14,895-Rp43,5000 per Mbps. And Singapore became the country with the cheapest tariff and the fastest internet service [16].

TABLE II. PARAMETER ESTIMATION RESUlT OF TRADE IN ITC COMMODITIES (MODEL 1B)

\begin{tabular}{|c|c|c|c|c|}
\hline Variables & Definition & Coef. & $\mathbf{z}$ & $\mathbf{P}>\mathbf{z}$ \\
\hline rgdp & $\begin{array}{l}\text { Ratio of GDP } \\
\text { between origin } \\
\text { and } \\
\text { destination } \\
\text { country }\end{array}$ & 1.939 & 0.650 & 0.518 \\
\hline linder & Linder effect & -6.814 & $-1.700 * *$ & 0.089 \\
\hline ddist & $\begin{array}{l}\text { Distant of two } \\
\text { countries }\end{array}$ & -4.756 & -1.220 & 0.223 \\
\hline liibr & $\begin{array}{l}\text { Int'l internet } \\
\text { bandwidth }\end{array}$ & -0.181 & -1.190 & 0.235 \\
\hline lfbir & $\begin{array}{l}\text { Fixed } \\
\text { broadband } \\
\text { internet tariffs }\end{array}$ & -0.148 & $-1.670 * *$ & 0.094 \\
\hline lqesr & $\begin{array}{l}\text { Quality of } \\
\text { educational } \\
\text { system }\end{array}$ & 0.187 & $1.320^{*}$ & 0.186 \\
\hline _cons & Intercept & 36.061 & 1.280 & 0.200 \\
\hline \multicolumn{5}{|c|}{$\begin{array}{l}\mathrm{R}^{2}: 0.996 \\
\text { Pseudo log-likelihood: }-109.874 \\
\text { RESET: chi2(1)=7.94**** } \\
\text { Endogenous variable: import between country (in level) }\end{array}$} \\
\hline
\end{tabular}

Note: $*^{* * *},{ }^{* * *},{ }^{* *},{ }^{*}:$ indicate significant at $\alpha=1$ percent, 5 percent, 10 percent, and 20 percent respectively

The next challenge is how to develop the basic abilities of every Indonesian man ready to face digitalization. From running data, when the quality of educational system increased, then ICT import would also increase by USD0.19 million, ceteris paribus. Unfortunately, in real life based on education statistic, Indonesian average of year schooling (age 15 years and over) reached only 8-9 year or in secondary education [17]. That has been exacerbated by the issue of honorary teacher condition and lack of education facilities in remote areas, even though education budget is earmarked by 20 percent of GDP.

However, the difference can be stimulated from an updated education system. It cannot teach only facts and theories, but also teach how to apply and elaborate that knowledge in the real life, including how to become an entrepreneur, geared for lifelong learning with the right kind of skills [18].

Services are becoming more tradable, and more traded, but statistical system for classifying and capturing those international transactions lags behind. ICT are the main enabling factor. Decreasing prices for voice and data communications, along with computerization of tasks, allow service providers to segment and relocate work to take advantage of large, remote pools of lower cost labor with the language and technical skills needed to deliver high quality services in a timely manner [19]. Because of the limitation of data, we cannot see the impact only in Indonesia and off course we cannot also elaborate ICT in services.

Table III and IV specifically discuss about the factors that influence the trade flow in services, particularly finance intermediation sector. Wherein it supported ICT trade. Table III indicated that GDP origin country, GDP destination country, readiness index, and CPI origin country effected import in service. As we can see, readiness index Indonesia and another ASEAN country positively influenced import in service. When ranking of readiness index increased 1 unit (or it meant ranking was worse off), import in service would increase by USD 0.42 million, ceteris paribus. It is in line with Ministry of Trade's report [20], according to the Hoekman Index, the largest ASEAN service sector is tourism, construction, and finance respectively $0.48,0.53$ and 0.33. This is in accordance with the Indonesian service sector which was opened in the $5^{\text {th }}$ ASEAN Framework Agreement on Services (AFAS). Basically, Indonesia has signed the $10^{\text {th }}$ Package of AFAS, for approximately 15 subsectors.

TABLE III. PARAMETER ESTIMATION RESUlt OF TRADE IN SERVICE (MODEL 2A)

\begin{tabular}{|c|c|c|c|c|}
\hline Variables & Definition & Coef. & $\mathbf{z}$ & $\mathbf{P}>\mathbf{z}$ \\
\hline lgdpo & $\begin{array}{l}\text { GDP } \\
\text { origin } \\
\text { country }\end{array}$ & 0.373 & $1.940 * *$ & 0.052 \\
\hline lgdppp & $\begin{array}{l}\text { GDP } \\
\text { destination } \\
\text { country }\end{array}$ & 0.886 & $13.550 * * * *$ & 0.000 \\
\hline ddist & $\begin{array}{l}\text { Distant of } \\
\text { two } \\
\text { countries }\end{array}$ & -0.007 & -0.470 & 0.635 \\
\hline lnrir & $\begin{array}{l}\text { Readiness } \\
\text { index }\end{array}$ & -0.416 & $-6.930 * * * *$ & 0.000 \\
\hline cpio & $\begin{array}{l}\text { CPI origin } \\
\text { country }\end{array}$ & 0.057 & $3.250 * * * *$ & 0.001 \\
\hline _cons & Intercept & -7.730 & $-4.880 * * * * *$ & 0.000 \\
\hline \multicolumn{5}{|c|}{$\begin{array}{l}\mathrm{R}^{2}: 0.802 \\
\text { Pseudo log-likelihood: }-163.938 \\
\text { RESET: chi2(1)=3.650*** } \\
\text { Endogenous variable: import between country (in level) }\end{array}$} \\
\hline
\end{tabular}

Trade in services is not about to replace merchandise trade as the leading trade sector. International trade in services is quite different from what we conventionally think of as the service industries. More than half of service exports are investment income and the very nature of the rest of services trade limits its potential growth. Furthermore, services are intricately tied with goodsproducing industries domestically and internationally, and the one will never replace the other [21].

In Table IV, we see more closely related to Indonesian and ASEAN readiness. It can be revealed that besides GDP destination country and CPI origin country, it turns out that individual readiness would affect trade in service positively. When the individual readiness rises by one unit (or it meant the ranking was worse off), then it would decrease imports in financial service by USD0.20 million, ceteris paribus. Individual readiness variable measures the readiness of a nation's citizens to utilize and leverage ICT. Factors that are used to measure this include literacy rates, mode and locus of 
access to the internet, and the degree of connectivity of individuals. So, higher imports in service, in turn, may contribute to economic growth and development and also the creation of new jobs. Changkyu [22] revealed that doubling of internet usage increase in services trade. An increase in a country's internet access will facilitate an increase in its service trade with other countries.

TABle IV. PARAmeter Estimation Result of Trade in SERVice (MODEL 2B)

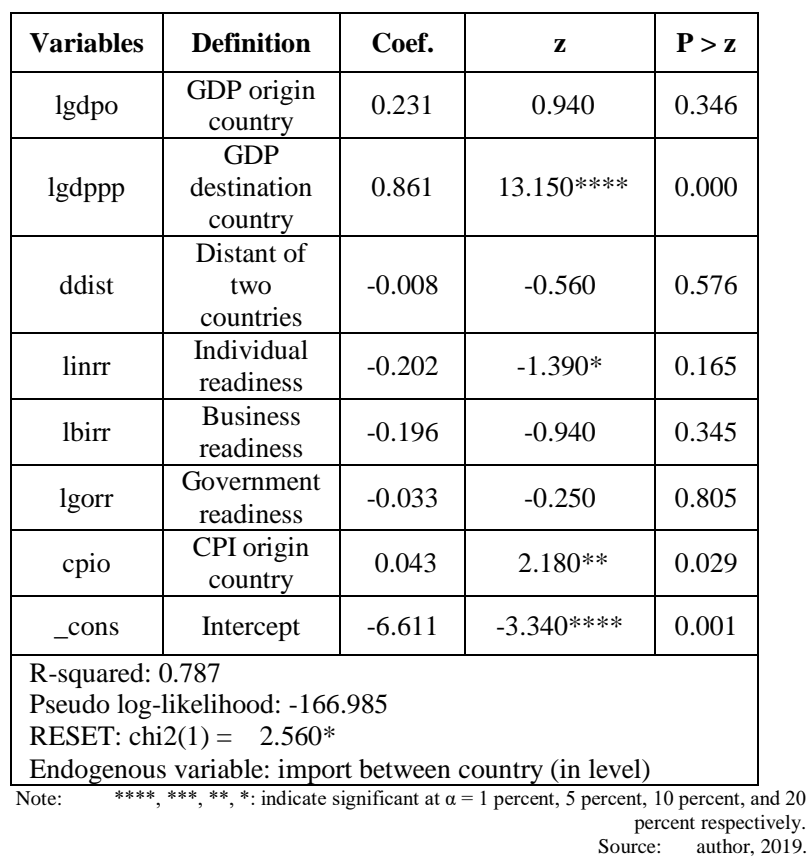

As we know that Indonesia still has a huge homework related to this individual readiness (skill), such as an upskilling or reskilling of workers based on the needs of today's industry. Digital skills are considered very potential to continue to be developed in Indonesia. Rapid advances in artificial intelligence (AI), robotics, and other emerging technologies are happening in ever shorter cycles, changing the very nature of the jobs that need to be done- and the skills needed to do them- faster than ever before. Therefore, the government will make digital skills one of the priorities for human resource development face digitalization.

\section{CONCLUSION AND POLICY RECOMMENDATION}

Indonesian readiness was an important factor in encouraging positively flow trade in ASEAN region, include tangible and intangible product related with digitalization. Its impact was recorded increasing trade flow by USD0.40 million until USD1 million. As for accessibility and individual skill (literacy) would became main concern (factors) how to be a true winner in ASEAN market.

Government has built a conducive digital ecosystem (namely infrastructure), to support national broadband quality. That is one of big step and should be combined with another factors, such as affordability in tariffs and develop individual digital literacy. In fact, affordability is not only about the lowest possible tariff but also how it can be accessed by all people in remote area. Last but not least, each individual must be fulfilled with knowledge and skills when using the digital technology to leverage their benefits.

\section{REFERENCES}

[1] cnn.com, "Potensi besar pasar indonesia hadapi ekonomi digital", 2018, (http://www.cnnindonesia.com/teknologi/20181102184855185-343600/potensi-besar-pasar-indonesia-hadapi-ekonomi-digital, accessed August 19, 2019)

[2\} kominfo.go.id, "Indonesia akan jadi pemain ekonomi digital terbesar di Asia Tenggara", 2015, (https://kominfo.go.id/index.php/content/detail/6441/

Indonesia+Akan+Jadi+Pemain+Ekonomi+Digital+Terbesar+di+Asia +Tenggara/0/berita_satker, accessed July 22, 2019).

[3] Pratomo, Y, “APJII: Jumlah pengguna internet di Indonesia tembus 171 juta jiwa”, 2019, (https://tekno.kompas.com/read/2019/05/16/03260037/apjii-jumlahpengguna-internet-di-indonesia-tembus-171-juta-jiwa, accessed July 22, 2019).

[4] katadata.co.id, "Indonesia, Raksasa teknologi digital Asia", 2015, (htpps//katadata.co.id/opini/2015/09/29 /indonesia-raksasateknologi-digital-asia, accessed August 19, 2019).

[5] Suominen, K, "Fuelling trade in the digital era: Policy roadmap for developing countries, Issue Paper, Geneva: International Centre for Trade and Sustainable Development, 2017.

[6] Manyika, J., Lund, S., Bughin, J., Woetzel, J., Stamenov, K, \& Dhingra, D., Digital globalization: The new era of global flows, London, San Francisco, Shanghai: McKinsey Global Institute, 2016.

[7] Vogiatzoglou, K., "Determinants of export specialization in ICT products: A cross-country analysis", Working Paper 2009.3, International Network for Economic Research, 2009.

[8] Zhongwei, X., "The impacts of Information and Communications Technology (ICT) and e-commerce on bilateral trade flows", International Economics and Economic Policy, Vol. 15, Issue 3, 2018, pp. 565-586

[9] Anderson, J.E., "A theoretical foundation for the Gravity Equation, The American Economic Review, Vol. 69, No. 1, 1979, pp. 106-116.

[10] Feenstra, R.C., Markusen, J.R., \& Rose, A.K., "Using the Gravity Equation to differentiate among alternative theories of trade", The Canadian Journal of Economics, Vol. 34, No. 2, 2001, pp. 430-447.

[11] Silva, J.M.C.S. \& Tenreyro, S., "The log of gravity", The Review of Economics and Statistics, Vol. 88, No. 4, 2006, pp. 641-658.

[12] Westerlund, J. \& Wilhelmsson, F., "Estimating the Gravity Model without gravity using panel data", Applied Economics, Vol. 43, 2011, 641-649.

[13] Akhvlediani T. \& Śledziewska, K., "Implications of the European integration: Revisiting the hypothesis of 'Hub-and-Spokes' Model", Baltic Journal of Economics, Vol. 17, No. 1, 2017, pp. 45-56.

[14] Lohmann, J., "Do language barriers affect trade?", Economics Letters, Vol. 110, 2011, pp. 159-162.

[15] WEF, The global information technology report, ICTs for inclusive growth, Geneva: World Economic Forum and INSEAD, 2015.

[16] Khairuddin, I., "Tarif internet kabel Indonesia termasuk yang mahal di Asia Tenggara", 2019, (https://selular.id /2019/04/tarif-internetkabel-indonesia-termasuk-yang-mahal-di-asia-tenggara/, accessed 16 August 2019).

[17] Gerintya, S., "Indeks pendidikan Indonesia rendah, daya saing pun lemah", 2019, (https://tirto.id/indeks-pendidikan-indonesia-rendahdaya-saing-pun-lemah-dnvR, accessed 16 August 2019).

[18] Dehaze, A., Education 2.0: Getting ready for the future of work, In Bruno Lanvin and Felipe Monteiro (Eds.), The Global Talent Competitiveness Index 2019, Entrepreneurial talent and global competitiveness, Fontainebleau, France: INSEAD, 2019.

[19] UNCTAD, "International trade in ICT services and ICT-enabled services", Technical Note No. 3, Geneva: United Nations Conference on Trade and Development, 2015.

[20] Ministry of Trade, "Laporan akhir, Analisis posisi perdagangan jasa Indonesia pada perundingan ACFTA”, Jakarta: Ministry of Trade, 2015.

[21] Landefeld, J.S., "International trade in services: Its composition, importance and links to merchandise trade", Business Economics, Vol. 22, No. 2, 1987, pp. 25-31 
[22] Cahngkyu, C., "The effect of the internet on service trade", Economics Letters, Vol. 109, 2010, pp. 102-104. 